\title{
STRATEGI PEMOTIVASIAN DALAM PEMBELAJARAN TAHFIZH AL-QUR'AN
}

\author{
Supian*, Sahrizal Vahlepi, dan Mar’atun Sholiha \\ Universitas Jambi, Indonesia \\ *E-mail:supian.ramli@unja.ac.id
}

\begin{abstract}
Abstact. This article examines motivating strategies in learning Tabfizh Al-Qur'an. The question in this study is what is the motivating strategies in learning Tabfirh Al-Qur'an applied at the Qur'an-Hadith School and the Integrated Islamic Boarding School Dar al-Masaleb Foundation, Jambi City. This type of research is qualitative research. Data is collected through participant observation, in-depth interviews, and documentation. To check the validity of the data, it is done by extending the participation, observation, and trigulation. The results of this study reveal that the strategy of motivation and learning tabfizh Al-Qur'an as follows: a) At first, arrange what you want to remember, b) Improve good communication between teachers and parents of students, c) Do not concentrate too much on memory material, d) Give prizes / sanctions, e) Give memorization targets, f) Create a pleasant atmosphere, and g) Hold student performances or take part in competitions. The supporting factors in learning Tabfizh Al-Qur'an are the motivation of the teacher and parents, conducive classroom atmosphere, the awareness of the students themselves and the good relationship between the teacher of tahfiøh, parents and students. Otherwise, it will become obstacles.
\end{abstract}

Keywords: Motivation Strategy, Tabfizh Al-Qur'an, Learning of Tabfirh Al-Qur'an

Abstrak. Artikel ini mengkaji strategi pemotivasian dalam pembelajaran Tahfiøh Al-Qur'an. Pertanyaan dalam penelitian ini adalah bagaimana strategi pemotivasian dalam Pembelajaran Tabfirh Al-Qur'an di Sekolah Qur'an Hadits dan Sains Yayasan pesantren Terpadu Dar alMasaleh Kota Jambi. Jenis penelitian ini adalah penelitian kualitatif. Pengumpulan data melalui metode observasi partisipan, wawancara mendalam, dan dokumentasi. Untuk mengecek keabsaban data, dilakukan dengan melakukan perpanjangan keikutsertaan, pengamatan, dan trigulasi. Hasil penelitian ini mengungkapkan bahwa strategi motivasi dan pembelajaran tahfiø. Al-Qur'an sebagai berikut: a) Mengatur terlebih dabulu apa yang hendak diingat, b) Memperbaiki komunikasi yang baik antara guru dan orang tua siswa, c) Jangan memusatkan terlalu banyak. bahan ingatan, d) Memberikan hadiah/sanksi, e) Memberikan target hafalan, f) Menciptakan suasana yang menyenangkan, g) Mengadakan pentas santri/siswa atau mengikuti kompetisi. Adapun faktor pendukung dalam pembelajaran Tabfizh Al-Qur'an adalah motivasi dari guru dan orang tua, suasana kelas yang kondusif, adanya kesadaran dari diri siswa dan adanya bubungan baik antara guru tahfizh, orang tua dan siswa. Jika sebaliknya maka akan menjadi faktor penghambat.

Kata Kunci : Strategi Pemotivasian, Tabfizh Al-Qur'an, Pembelajaran Tabfizh Al-Qur'an

TARBAWY: Indonesian Journal of Islamic Education - Vol. 6 No. 2 (2019) 


\section{PENDAHULUAN}

Al-Qur'an adalah kitab suci yang diturunkan oleh Allah SWT kepada Nabi Muhammad SAW sebagai petunjuk sekaligus sebagai penyempurna dari kitab-kitab suci sebelumnya. Dan AlQur'an adalah kitab Allah SWT yang mulia dan dijaga oleh Allah SWT dari segala bentuk penyimpangan dan perubahan. Hal ini ditegaskan Allah SWT dalam Firman-Nya:

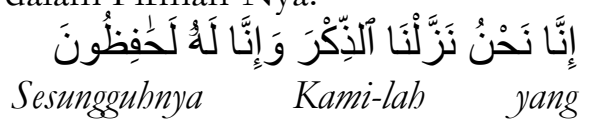
menurunkan Al Quran, dan sesunggubnya Kami benar-benar memelibaranya. Q.S. AlHijr: 9.

Dengan adanya jaminan Allah SWT pada ayat diatas bukan berarrti umat islam terlepas dari tanggung jawab dan kewajiban untuk memelihara kemurnian Al-Qur'an. Allah SWT dalam menjaga Al-Qur'an melibatkan para hambanya. Salah satu cara yang dapat dilakukan oleh kaum islam untuk ikut ambil bagian dalam memelihara AlQur'an adalah dengan menghafalnya atau sering membacanya karna Al-Qur'an Adalah kalamullah yang merupakan mukjizat yang diturunkan kepada Nabi Muhammad SAW dan ditulis di mushaf serta diriwayatkan dengan mutawtir, membacanya termasuk ibadah. (Supian dkk, 2018: 13)

Bagi orang yang menghafal AlQur'an maka dijamin sukses hidupnya didunia dan di Akhirat kelak bukan hanya bagi dirinya sendiri tapi juga bagi keluarga dan terutma kedua orang tuanya, aktivitas menghafal al-Qur'an hukumnya fardlu kifayah yang menjadikan seorang penghafal memiliki kedudukan mulia di dunia dan di akhirat, karena para penghafal al- Qur'an adalah orang-orang yang menjaga keaslian al-Qur'an dari kepalsuan dan kerusakan. Menghafal alQur'an merupakan bentuk jaminan Allah terhadap otentisitas al-Qur'an. Oleh karena itu, Allah telah memudahkan umat Islam yang mau membaca, menghafal, dan menelaah al-Qur'an. (Hidayah, 2016).

Dewasa ini banyak orang yang ingin menghafal Al-Qur'an tetapi mereka khawatir dan takut akan persoalan jika tidak bisa menjaganya. Bahkan tidak banyak penghafal Al-Qur'an merasa bahwa aktifitas menghafal adalah beban dan membosankan, sehingga tidak sedikit para penghafal Al-Qur'an putus harapan ditengah jalan (tidak mampu menyelesaikan hafalan 30 juz) dan tidak dapat menjaga hafalan yang telah dihafalnya. Disanalah peran para guru sebagai pendidik dalam pememotivasian siswa dalam pembelajaran tahfidz atau menghafal Al-Qur'an di sekolah atau dipesantren.

Strategi dikatakan berhasil apabila tujuan dan akhir dari pembelajaran itu tercapai,begitu juga dalam pembelajaran tahfizhul Qur'an atau menghafal AlQur'an strategi yang baik akan berpengaruh pada kualitas dan kuantitas hafalan yang baik pula dan proses belajar mengajar berjalan secara efektif dan benar. Tanpa strategi yang jelas, proses pembelajaran tidak akan terarah sehingga tujuan pembelajaran yang telah ditetapkan sulit tercapai secara optimal, dengan kata lain pembelajaran tidak dapat berlangsung secara efektif dan efisien. (Made, 2013: 3) Guru diharuskan memiliki strategi yang tepat agar peserta didik dapat belajar secara efektif dan efisien sesuai dengan tujuan yang diharapkan.

Berdasarkan hasil observasi yang dilakukan oleh peneliti di Sekolah Qur'an Hadits dan Sain Yayasan Pesantren Terpadu Dar al-Masaleh kota Jambi, bahwasannya sekolah ini telah memiliki program unggulan berupa "Tahfizh AlQur'an". Kegiatan tahfizh Al-Qur'an dilakukan setiap hari pada jam sekolah dan kegiatan ini tujuannya untuk membiasakan siswa agar mampu menghafal Al-Qur'an dengan baik dan 
benar. Namun pada pelaksanannya, masih ada beberapa kendala yang dialami oleh guru dalam melakukan pembelajaran ini sehingga diperlukan suatu strategi, metode, teknik, serta taktik motivasi untuk menunjang kegiatan pembelajaran Tahfizh AlQur'an agar berjalan sesuai dengan tujuan yang diinginkan. (Observasi pada Februari 2019) Sekolah ini dipilih menjadi tempat penelitian karena program tahfizh Al-Qur'an menjadi program unggulan disamping pembelajaran Hadits, Sain dan pembelajaran lainnya.Sekolah ini memiliki banyakprestasi terutama dibidang tahfizh Al-Qur'an. Selain bidang-bidang akademik, juga diberikan keterampilan hidup (life-skills), sains teknologi, dan pendidikan agama yang menjiwai seluruh pembelajaran; dalam kehidupan sehari-hari, dengan mengedepankan pengolahan ranah kognitif, afektif dan psikomotor. Berdasarkan uraian diatas, peneliti tertarik untuk menggali lebih dalam tentang "Strategi motivasi dan pembelajaran Tabfizh Al-Qur'an di Sekolah Qur'an Hadits dan Sains Yayasan Pesantren Terpadu Dar alMasaleb Kota Jambi"

Permaslah-permasalahan dalam penelitian ini adalah:

1. Bagaimana strategi pemotivasian dalam pembelajaran Tahfizh AlQur'an di Sekolah Qur'an Hadits dan Sains Yayasan Pesantren Terpadu Dar al-Masaleh kotaJambi?

2. Apa saja faktor-faktor pendukung dan penghambat guru dalam pemotivasian dalam pembelajaran tahfizh Al-Qur'an di Sekolah Qur'an Hadits dan Sains Yayasan Pesantren Terpadu Dar al-Masaleh kota Jambi?

3. Bagaimana strategi pemotivasian dalam pembelajaran tahfizh AlQur'an di Sekolah Qur'an Hadits dan Sains Yayasan Pesantren Terpadu Dar al-Masaleh kotaJambi?

Adapun tujuan dari penelitian ini adalah :

1. Untuk mengetahui strategi dalam pelaksanaan pembelajaran Tahfizh Al-Qur'an di Sekolah Qur'an Hadits dan Sains Yayasan Pesantren Terpadu Dar al-Masaleh kota Jambi

2. Untuk mengetahui faktor pendukung dan penghamabat dalam peningkatan kualitas hafalan siswa dalam pembelajaran Tahfizh AlQur'an di Sekolah Qur'an Hadits dan Sains Yayasan Pesantren Terpadu Dar al-Masaleh kota Jambi Untuk mengetahui bagaimana teknik, strategi motivasi dan pembelajaran tahfizh Al-Qur'an di Sekolah Qur'an Hadits dan Sains Yayasan Pesantren Terpadu Dar al-Masaleh kota Jambi

\section{METODE PENELITIAN}

Penelitian ini menggunakan metode kualitatif, Penelitian ini merupakan sebuah studi yang akan mengungkapkan, menemukan dan menggali informasi tentang strategi pemotivasian dalam pembelajaran Tahfidz Al-Qur'an di Sekolah Qur'an Hadits dan Sains Yayasan Pesantren Terpadu Dar alMasaleh kota Jambi. Pendekatan kualitatif dipilih dengan alasan sesuai dengan kajian ini yang digunakan untuk menguraikan, menggambarkan, menggali informasi mengenai sekolah yang bergerak dibidang Tahfizh Al-Qur'an tersebut, pendekatan kualitatif yang dimaksud adalah bahwa terlebih dahulu peneliti mencari literatur atau teori yang berkaitan dengan penelitian, kemudian teori tersebut dibandingkan dengan kondisi lapangan penelitian. Pengumpulan data dilakukan oleh peneliti untuk memperolah informasi data-data yang diinginkan, peneliti dalam hal ini menerapkan beberapa teknik sebagai berikut: 
1. Observasi

Teknik observasi berguna untuk alat pengumpulan data utama dari subjek dan objek penelitian di Sekolah Qur'an Hadits dan Sains Yayasan Pesantren Terpadu Dar alMasaleh kota Jambi, pada teknik observasi ini peneliti mendatangi Sekolah Qur'an Hadits dan Sains Yayasan Pesantren Terpadu Dar alMasaleh kota Jambi disini peneliti melihat dan mengamati proses pembelajran Tahfizh Al-Qur'an khususnya informan dan reseponden yang mengetahui permasalahan strategi peMotivasian dan Pembelajaran Tahfizh AlQur'an di Sekolah Qur'an Hadits dan Sains Yayasan Pesantren Terpadu Dar al-Masaleh kota Jambi.

1. Wawancara

Wawancara digunakan untuk mendapatkan informasi dari subjek penelitian, pada teknik wawncara ini peneliti bertanya dan mewancarai ketua Yayasan kepala sekolah dan guru serta siswa di Sekolah Qur'an Hadits dan Sains Yayasan Pesantren Terpadu Dar al-Masaleh kota Jambi, yang memberikan keterangan tentang Strategi pemotivasian dalam Pembelajaran Tahfizh Al-Qur'an di Sekolah Qur'an Hadits dan Sains Yayasan Pesantren Terpadu Dar al-Masaleh kota Jambi.

2. Dokumentasi

Dokumentasi digunakan sebagai alat pengumpulan data pendukung dari observasi di Sekolah Qur'an Hadits dan Sains Yayasan Pesantren Terpadu Dar alMasaleh kotaJambi. Adapun data yang diperoleh melalui dokumentasi adalah data-data tentang historis dan geografis, struktur organisasi, sarana prasarana, proses pembelajaran Tahfidz Al-Qur'an.

Teknik yang dilakukan dalam melakukan analisis data ini adalah data yang diperoleh dari hasil observasi, wawancara dan dokumentasi akan diolah/diuraikan secara khusus untuk kemudian menyimpulkan dalam bentuk umum/general. Agar memperoleh data yang benar-benar valid atau sah maka untuk menjaga keabsahan data yang sudah ada atau di peroleh, maka peneliti menggunakan tehnik Trianggulasi dan memperpanjang masa observasi. Trianggulasi adalah mengecek kebenaran data tertentu dengan membandingkannya dengan data yang diperoleh dari sumber lain. Memperpanjang masa observasi. Hal ini dilakukan untuk betulbetul mengenal suatu lingkungan, mengadakan hubungan yang baik dengan orang-orang dilokasi penelitian. hal ini juga peneliti lakukan jika terdapat kekurangan data maka peneliti langsung kembali kesekolah Qur'an Hadist dan Sains Dar Masaleh kota Jambi untuk menyempurnakan data agar data yang didapatkan bisa dipertanggung jawabkan keabsahannya.

\section{HASIL PENELITIAN DAN PEMBAHASAN}

Penelitian ini dilakukan di Sekolah Qur'an Hadits dan Sains School Dar alMasaleh Jambi. Status sekolah adalah swasta milik Yayasan Pesantren Terpadu Dar al-Masaleh Jambi. sejak tanggal 1 April 2019 sampai dengan 27 Agustus 2019.

Setelah melakukan penelitian tentang strategi pemotivasian dalam pembelajaran Tahfizh di Sekolah Qur'an Hadits dan Sains Yayasan Pesantren 
Terpadu Dar al-Masaleh kota Jambi dengan metode observasi, wawancara, dan dokumentasi dapat ditemukan hasil penelitian sebagai berikut

Temuan penelitian yang dimaksudkan disini adalah mengungkapkan data yang diperoleh dari hasil penelitian lapangan yang sesuai dengan masalah yang ada di dalam pembahasan ini. Setelah melakukan penelitian di Sekolah Qur'an Hadits dan Sains Yayasan Pesantren Terpadu Dar alMasaleh kota Jambi dapat dikemukakan temuan penelitian sebagai berikut:

\section{Strategi Pemotivasian Dalam Pembelajaran Tahfizh Al-Qur'an Pada Siswa}

Beberapa temuan penelitian tentang strategi guru dalam meningkatkan motivasi dalam pembelajaran tahfizh Al-Qur'an pada siswa di Sekolah Qur'an Hadits dan Sains Yayasan Pesantren Terpadu Dar al-Masaleh kota Jambi yaitu:

a. Menumbuhkan minat tahfizh AlQur'an pada siswa merupakan salah satu cara untuk memotivasi hafalanya. Guru dapat menumbuhkan minat. Tujuannya agar siswa tidak terlalu jenuh. Di Sekolah Qur'an Hadits dan Sains Yayasan Pesantren Terpadu Dar al-Masaleh kota Jambi ini siswa SD ditargetkan Minimal Hafal 5 Juz Al-Qur'an hinnga kelas IV.

b. Mengatur terlebih dahulu apa yang hendak kita ingat. Menghafal urutan-urutan ayat yang dihafalkannya setelah hafal ayatnya. Dengan demikian siswa mudah menghafal ayat selanjutnya.

c. Memperbaiki setiap ingatan yang salah jangan biarkan berlarutlarut dalam hafalan Al-Qur'an.

d. Jangan memusatkan terlalu banyak bahan ingatan. Ingatlah sesuai target hafalan. e. Memberikan hadiah atau sanksi. Memberikan hadiah kepada siswa yang berprestasi dalam tahfizhnya dapat menumbuhkan motivasi siswa untuk lebih giat lagi dalam menghafal Al-Qur'an. Pemberian hukuman dapat berupa tetulis maupun tidak tertulis. Seperti maju kedepan dan menulis surah-surah pendek.

f. Memberikan target hafalan, target merupakan suatu pekerjaan yang menuntut untuk diselesaikan. Memberikan target yang menjadi tugas di rumah bisa menjadi salah satu langkah memotivasi hafalan siswa.

g. Menciptakan suasana yang kondusif. Siswa dapat menghafal dengan baik jika dalam suasana yang kondusif. Sehingga anak dapat menghafal sesuai target dari guru tahfizh

h. Mengadakan kompetisi atau pentas Santri Salah satu cara yang digunakan oleh guru tahfizh untuk meningkatkan motivasi siswa. Karena di dalam kompetisi inilah siswa bisa menunjukkan tingkat menghafalnya masing-masing.

2. Faktor- Faktor Pendukung Strategi Pemotivasian Dalam Pembelajaran Tahfizh Al-Qur'an Beberapa faktor pendukung pemotivasian dalam pembelajaran tahfizh Al-Qur'an pada siswa di Sekolah Qur'an Hadits dan Sains Yayasan Pesantren Terpadu Dar al-Masaleh kota Jambi adalah sebagai berikut:

a. Adanya dukungan motivasi dari guru dan orang tua, Di sekolah guru menjadi orang tua siswa sedangkan dirumah orang tua menjadi guru dalam kehidupan anak. Guru dan orang tua harus meningkatkan motivasi agar anak tidak malas untuk menghafalan Al-Qur'an karena itu sangat berguna bagi tingkat lanjutannya dan kehidupan sehari-hari. 
b. Suasana kelas yang kondusif , Suasana kelas yang kondusif sangat mendukung program tahfizh AlQur'an di kelas. Dengan suasana kelas yang kondusif peserta didik akan lebih mudah menghafalkan. Guru tahfizh juga akan lebih mudah mengkondisikan peserta didik sehingga tujuan agar mudah tercapai.

c. Adanya kesadaran dari diri siswa, Adnya kesadaran dari diri peserta didik menjadi faktor utama dalam upaya meningkatkan motivasi tahfizh Al-Qur'an. Jika sudah ada kesadaran dalam diri peserta didik tentang pentingnya tahfizh, maka guru tahfizh akan lebih mudah untuk meningkatan motivasi tahfizh Al-Qur'an siswa tersebut.

d. Hubungan yang baik antara guru tahfizh dan siswa, Hubungan yang baik antara guru tahfizh dan peserta didik sangat berpengaruh terhadap lancer atau tidaknya suatu progam tahfizh ini. Jika hubungan antara guru tahfizh dan siswa tidak terjalin baik, maka program tahfizh juga tidak akan berjalan dengan baik pula, hal ini menjadi ketidak nyamanan siswa. Guru pun juga akan sulit dalam memotivasi siswa.

3. Faktor- Faktor Penghambat Dalam Strategi Pemotivasian Dalam Pembelajaran Tahfizh Al-Qur'an

Beberapa faktor penghambat strategi pemomotivasian siswa di Sekolah Qur'an Hadits dan Sains Yayasan Pesantren Terpadu Dar alMasaleh kota Jambi adalah sebagai berikut:

a. Kurangnya perhatian dari orang tua, Kurangnya perhatian dari sebagian orang tua yang sibuk dengan pekerjaanya, membuat peserta didik bermalas-malasan dan tidak termotivasi dalam tahfizhnya, karena anak merasa kurang diperhatikan orang tua di rumah.

b. Kondisi lingkungan yang kurang kondusif, Di dalam kelas yang kurang kondusif untuk pembelajaran tahfizh Al-Qur'an seperti adanya siswa yang menjaili temanya dan bejalan-jalan, sehingga membuat hafalan temanya terganggu.

c. Kurang lengkapnya sarana dan prasarana, Sarana yang kurang memadai juga menjadi penghambat dari upaya guru tahfizh dalam meningkatkan motivasi tahfizh AlQur'an. Seperti siswa lupa tidak membawa buku setoran Hafalan. Dan keadaan kelas menjadi membosankan jika hanya hafalan saja dan tidak ada sesuatu yang baru.

d. kesadaran siswa sendiri, faktor penghambat yang paling utama demi lancarnya upaya guru tahfizh dalam meningkatkan motivasi Tahfizh Al-Qur'an adalah kesadaran siswa yang tumbuh dari dalam anak sendiri untuk menghafal. Tanpa adanya kesadran dalam diri, siswa tidak akan termotivasi.

4. Strategi Pemotivasian Dalam Mengatasi Hambatan-Hambatan Dan Pembelajaran Tahfidzh AlQur'an Pada Siswa

Cara mengatasi hambatanhambatan dalam meningkatkan motivasi dan pembelajaran tahfizh Al-Qur'an di Sekolah Qur'an Hadits dan Sains Yayasan Pesantren Terpadu Dar al-Masaleh kota Jambi adalah sebagai berikut:

a. Menggunakan variasi strategi motivasi dan pembelajaran tahfizh Al-Qur'an Variasi strategi motivasi dan pembelajaran tahfizh AlQur'an agar siswa tidak merasa jenuh selama mengikuti proses tahfizh Al-Qur'an.

b. Adanya peraturan dan sanksi, Adanya peraturan dan sanksi yang 
sifat nya mendidik saat melanggar peraturan yang di buat guru tahfizh. Tujuanya siswa agar disiplin dan tidak ramai sendiri, kedisiplinan sangat mendukung kualitas hafalan siswa.

c. Kerja sama yang baik antara guru tahfizh dengan orang tua siswa Guru tahfidzh dan guru tahfizh paling berpengaruh dalam meningkatkan motivasi. Kerja sama ini akan menumbuhkan motivasi yang luar biasa.

d. Pemenuhan kelengkapan sarana dan prasarana, Dukungan dari sarana tahfizh Al-Qur'an sangat penting membantu guru. Ruang kelas yang nyaman dan tenang merupakan kunci strategi untuk melaksanakan pembelajaran Tahfizh Al-Qur'an.

\section{PEMBAHASAN}

Strategi merupakan suatu seni untuk melaksanakan sesuatu secara baik atau terampil. Itulah sebabnya, strategi pembelajaran dipaki sebagai suatu seni untuk membawa peserta didik kedalam suasana pembelajaran dan berada pada posisi yang menguntungkan. Strategi identik dengan metode atau teknik, yaitu cara menyampaikan pesan dalam hal ini materi pembelajaran kepada peserta didik yang bertujuan untuk mencapai tujuan-tujuan belajar yang telah ditetapkan. (Haidir dan salim, 2014: 99).

Para guru dan Siswa Sekolah Qur'an Hadits dan Sains Yayasan Pesantren Terpadu Dar al-Masaleh kota Jambi berusaha untuk menerapkan strategi pemotivasian yang tepat dalam pembelajaran Tahfizh Al-Qur'an, karena disekolah Qur'an Hadits dan Sains Yayasan Pesantren Terpadu Dar alMasaleh kota Jambi ini berbeda-beda motivasinya dalam menghafal Al-Qur'an sehingga salah satu strategi yang di lakukan adalah dengan menjalin hubungan antara guru dan orang tua siswa dan siswa dengan guru, selain itu juga pemotivasian pembelajran Tahfizh Al-Qur'an yang dilakukan oleh guru adalah guru mengajak anak-anak untuk sambil bermain tetapi tetap didengarkan dengan bacaan-bacaan Al-Qur'an dan itu terus diulang-ulang, karena dengan sering mendengar bacaan Al-Qur'an yang diualng-ulang akan membuat siswa cepat hafal.

Dalam pembelajaran Tahfizh Alqur'an ada juga guru yang menerapkan Metode muroja'ah adalah metode mengulang atau memuroja'ah bacaan $\mathrm{Al}$ Qur'an. Metode ini menekankan pada pengulangan agar hafalannya tidak hilang. (13Yahya bin Abdurrazaq al-Ghausani, 2014: 127) Tujuan dari muraja'ah atau mengulang ialah supaya hafalan yang sudah penghafal hafalkan tetap terjaga dengan baik, kuat dan lancar. (Abdul Aziz Abdul Ra'uf, 2009: 125)

Strategi yang saya pakai untuk pembelajaran tahfizh Al-Quran ini ialah strategi mengulang-ulang perayat AlQur'an. Menurut saya strategi ini sangat efektif untuk digunakan dalam pembelajaran Tahfizh Al-Quran, karena cara mengajarnya itu sedikit-sedikit dulu dari 1 ayat dan siswa menyimak ketika guru/ustdzah membaca, setelah itu dibaca bersama-sama. Dan di baca secara berulang-ulang agar semua siswa lebih cepat hafal.( Wawancara ustazah Adilla, S.Pd. guru kelas 4 SD Wawancara ustazah Adilla, S.Pd. pada tanggal 10 April 2019 pada tanggal 10 April 2019)

Menurut Wiwi Alawiyah Wahid yang di kutib dalam buku Cara Cepat Bisa Menghafal Al-Qur'an menerangkan bahwa: Metode sema'an atau (Tasmi') adalah memperdengarkan hafalan kepada orang lain, misalnya kepada sesama teman tahfiæh atau kepada senior yang lebih lancar. (Alawiyah Wahid, 2015: 98)

Di Sekolah Qur'an Hadist dan Sains Dar masaleh jambi metode ini juga dilakukan oleh guru stelah memberi tugas dan mengajak siswa untuk menghafal atau bagi siswa yang telah 
mempunyai hafalan dengan mengadakan pentas santri setiap semeste maka disinalah siswa disema' dan di soal hafalannya. Dengan strategi ini siswa atau penghafal Al-Qur'an akan merasa termotivasi dengan hafalannya karena didengarkan dengan bacaa-bacaan $\mathrm{Al}$ Qur'an. (Wawancara dengan ketua yayasan ustadzah Dewi Rafiqah Syahdi, S.Pd., Pada tanggal 29 April 2019) Mengajarkan anak menghafal al-Qur'an dengan metode ini adalah dengan cara membacakan terlebih dahulu ayat yang dihafal secara berulang-ulang hingga anak menguasainya. Setelah anak menguasai, maka berpindah ke ayat selanjutnya. (Fathin Masyhud dkk. Sukses 3 Hafirh Qur'an Cilik Mengguncang Dunia: 2016: 229)

Pemotivasian dalam pembelajran Tahfizh Al-Qur'an merupakan usahausaha yang mendorong seseorang untuk belajar. Kuatnya motivasi yang dimiliki seorang anak akan menentukan kualitas perilaku yang ditampilkannya dalam konteks belajar maupun dalam kehidupan disekitarnya. Motivasi tumbuh dalam diri seseorang yang merupakan dorongan diri sendiri karena adanya sesuatu yang di anggap penting. Selain itu, motivasi juga bisa berpengaruh dari luar individu, misalnya guru, orang tua dan lingkungan sekitar. Maka para guru sekolah Qur'an Hadist dan sains Dar masaleh jambi selalu membangun motivasi siswa baik lewat lingkungan sekolah yang menarik ataupun cerita-cerita dan menjaga hubungan koordinasi dengan orang tua siswa agar motivasi siswa terus tumbuh untuk menghafal Al-Qur'an.

Hal ini sesuai hasil wawancara dengan kepala sekolah Ustadz M. Quzwen, S.Pd., pada tanggal 30 April 2019, pendukung pemotivasian peserta didik adalah adanya perhatian dari orang tua. Karena pulang sekolah itu tanggung jawabnya orang tua masing-masing. Makanya kami terus membangun komunikasi terhadap orang tua siswa dalam perkembangan pembelajaran tahfizh Al-Qur'an.

Istilah motivasi berasal dari kata motif yang diartikan sebagai kekuatan yang terdapat dalam individu, yang menyebabkan individu tersebut bertindak atau berbuat. Motif tidak dapat diamati secara langsung, tetapi dapat diinterpretasikan dalam tingkah lakunya, berupa rangsangan, dorongan, atau pembangkit tenaga munculnya suatu tingkah laku. (Hendri Jaya, 2018: 11)

Motivasi dalam perspektif islam ialah mengerjakan sesuatu atas dasar niat. Niat menjadi landasan amal dan ibadah seluruh umat islam. Kualitas aktivitas yang berkualitas dibangun dengan niat yang benar.Rasulullah SAW bersabda;

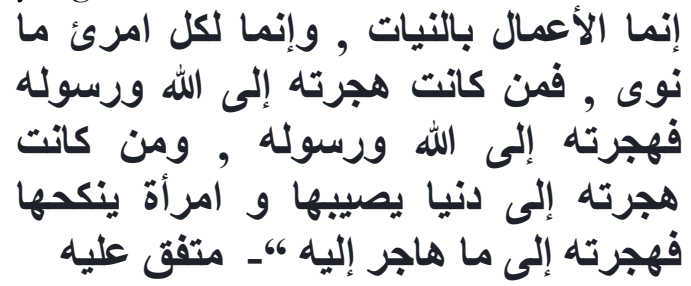

Segala amal itu tergantung niatnya, dan setiap orang banya mendapatkan sesuai niatnya.Maka barang siapa yang hijrahnya kepada Allah dan Rasul-Nya, maka bijrabnya itu kepada Allab dan RasulNya.Barang siapa yang bijrabnya itu Karena kesenangan dunia atau karena seorang wanita yang akan dikawininya, maka bijrabnya itu kepada apa yang ditujunya. (H.R Bukhari no. 1 dan Muslim no. 1907).

Segala aktivitas belajar mengajar dan mencari ilmu semuanya karena berdasarkan kepada motivasi dan niatan bentuk ibadah kepada Allah SWT termasuk aktivitas pembelajaran tahfihz Al-Qur'an. Di Sekolah Qur'an Hadits dan Sains Yayasan Pesantren Terpadu Dar al-Masaleh kota Jambi Menghafal Al Qur'an (tahfidz Al-Qur'an) merupakan suatu aktivitas belajar yang menekankan kepada kemampuan kognitif dalam mengingat ayat Al Qur'an. Menghafal Al Qur'an sebagai metode dan langkah awal 
belajar sebelum metode pembelajaran yang lainnya.

Dalam pembelajaran tahfizh AlQur'an tentu ada hambatan-hambatan yang dihadapi oleh siswa ataupun guru sperti seperti tidak adanya dukungan motivasi dari orang tua, suasana kelas yang tidak kondusif, tidak adanya kesadaran dari diri siswa dan tidak adanya hubungan baik antara guru tahfizh, orang tua dan siswa. Di Sekolah Qur'an Hadis dan sains dar-Almasaleh Jambi ini memiliki kelas yang nyaman dan menyenangkan yang dihiasi dengan tulisan-tulisan dan gambar-gambar yang edukatif sehingga siswa betah berada didalam kelas Susasana kelas pun menjadi kondusif dan membuat peserta didik tenang dan dapat meningkatkan konsentrasi hafalannya. (Wawancara dengan Noviani, S.hum., guru kelas 5 pada tanggal 30 April 2019) Oleh karena itu seorang guru selain memiliki motivasi dan strategi dalam mengajar, guru juga sudah hafal Al-qur'an (hafizh), menghafal atau Tahfizh merupakan suatu pekerjaan yang mulia disisi Allah SWT. (Sa'dullah, 2008: 25) Sedangkan Al-Qur'an menurut bahasa berarti bacaan atau yang dibaca. (Farid Esack, 2007: 65) Sehingga hafalan Al-Qur'an adalah orang yang berusaha dengan cermat memasukkan atau mengingat isi Al-Qur'an secara teliti ke dalam hatinya untuk selalu diingat dan dijaga secara terus-menerus sehingga apa yang telah dihafalkan dari Al-Qur'an benar-benar bisa meresap kuat ke dalam jiwa, akal dan jasadnya.

Pemotivasian yang guru lakukan dalam pembelajaran Tahfizh Di Sekolah Qur'an Hadits dan Sains Yayasan Pesantren Terpadu Dar al-Masaleh kota Jambi adalah dengan menggunakan strategi bermain dan menggunakan berbagai metode misalnya Talaqqi, Tahfizh dan semaan, kemudian juga mengadakan pentas santri atau mengikuti perlombaan seperti MTQ dan memberi reward kepada siswa yang mencapai target hafalan dan menegakkan kedisiplinan ketika ada siswa yang melanggar atau membuat suasana menjadi tidak kondusif dikelas dan bercerita kisah-kisah orang yang hafal Al-Qur'an, banyaknya orang yang hafal Al-Qur'an menunjukkan bahwa kegiatan menghafal Al-Qur'an itu relatif mudah, Al-Qur'an sudah mengisyaratkan hal tersebut dalam surah Al-Qomar Ayat 17, 22, 32, dan 40. Penggunaan kata "qad" yang didahului "lam ta'kid" (lam untuk mengokohkan makna) memberikan pengertian bahwa Allah ikut terlibat dalam peristiwa memudahkan Al-Qur'an. (Ahsin Skho Muhammad, 2017: 16)

Di sekolah Qur'an Hadits dan Sains Yayasan Pesantren Terpadu Dar al-Masaleh kota Jambi ini siswa ditargetkan hafal minimal 5 Juz AlQur'an dimulai dari Juz 30,29,28,27 dan 26. Sebagaimana yang disampaikan oleh kepala Sekolah " selain menghafal AlQur'an siswa juga dibekali dengan ilmuilmu lain seperti hadist dan sains atau ilmu umum lainnya maka kami disini hanya menrgetkan Hafalan siswa minimal 5 juz walaupun demikian ada juga siswa yang hafal ebih dari 5 juz. Wawancara dengan kepala sekolah Ustadz M. Quzwen, S.Pd.) berbeda dengan penelitian sebelumnya yang dilakukan oleh Ferdinan. Pelaksanaan Progam Tahfidz Al Qur'an. (Studi Pesantren Darul Arqam Muhammadiyah Gombara Sulawesi Selatan). Dalam Jurnal Tarbawi pendidikan Agama Islam Volume 3 No.1, Januari - Juni 2018 ISSN : 2527-4082.)

Beliau mengatakan bahwa di Studi Pesantren Darul Arqam Muhammadiyah Gombara Sulawesi Selatan Program Tahfidz Al- Qur'an 30 juz diselesaikan dalam waktu $2-3$ tahun dengan asumsi 10 juz pertahun (tergantung kepada kemampuan santri) dimana sambil menghafal Al-Qur'an dengan tajwid dan tartil, setiap santri juga mempelajari ilmu 
aqidah dasar, fiqh harian, sirah (sejarah), adab dan sunnah, hadits, nahwu, shorof, tafsir dan terjemah Qur'an.

Sementara di Sekolah Qur'an Hadits dan Sains Yayasan Pesantren Terpadu Dar al-Masaleh kota Jambi ini siswa hanya 5 juz dalam 6 tahun dikarenakan juga disekolah ini siswa tidak mentap disekoah sebagaimana pesantren.

\section{KESIMPULAN}

Berdasarkan temuan dan pembahasan diatsa dapat diambil kesimpulan penelitian sebagai berikut:

1. Strategi pemotivasian dalam pembelajaran Tahfizh yang dilakukan oleh guru dalam meningkatkan tahfizh Al-Qur'an di sekolah Qur'an Hadits dan Sains Yayasan Pesantren Terpadu Dar al-Masaleh kota Jambi sudah berjalan cukup baik. Hal ini dapat terlihat adanya usaha dari para guru. Diantara langkah guru dalam strategi motivasi dan pembelajaran tahfizh Al-Qur'an terhadap adalah sebagai berikut: a) Mengatur terlebih dahulu apa yang hendak diingat , b) Memperbaiki komunikasi yang baik antara guru dan orang tua siswa c) Jangan memusatkan terlalu banyak bahan ingatan d) Memberikan hadiah/sanksi, e) Memberikan target hafalan, f) Menciptakan suasana yang menyenangkan, g) Mengadakan pentas santri/siswa atau mengikuti kompetisi.

2. Faktor-faktor pendukung dan penghambat guru dalam meningkatkan motivasi dalam pembelajaran tahfizh Al-Qur'an di sekolah Qur'an Hadits dan Sains Yayasan Pesantren Terpadu Dar al-Masaleh kota Jambi sebenarnya hampir sama, seperti adanya dukungan motivasi dari guru dan orang tua, suasana kelas yang kondusif, Adanya kesadaran dari diri siswa dan adanya hubungan baik antara guru tahfizh, orang tua dan siswa. Dari faktor-faktor motivasi dan pembelajaran tahfizh Al-Qur'an tersebut siswa dapat menjadi faktor pendukung yang baik. Jika sebaliknya, maka hal tersebut menjadi faktor penghambat bagi siswa.

3. Cara guru dalam mengatasi hambatan-hambatan untuk meningkatkan strategi pemotivasian dalam pembelajaran tahfizh AL-Qur'an pada siswa di sekolah Qur'an Hadits dan Sains Yayasan Pesantren Terpadu Dar al-Masaleh kota Jambi, yaitu diantaranya a) Menggunakan variasi strategi dan metode pembelajaran tahfizh Al-Qur'an, b) Adanya peraturan reward dan sanksi, c) Kerja sama yang baik antara guru tahfizh dengan orang tua siswa, d) Pemenuhan kelengkapan sarana dan prasarana, e) mengadakan perlombaan atau pentas santri/siswa

\section{REFERENSI}

Departemen Agama RI. (2005) Al-Qur'an Terjemah. CV.Penerbit -Jakarta

Esack, Farid. (2007). Samudra AlQur'an. Yogyakarta: Diva Press

Fathin Masyhud dkk.( 2016). Rahasia Sukses 3 Hafizh Qur'an Cilik Mengguncang Dunia. Jakarta: Zikrul Hakim

Ferdinan. Pelaksanaan Progam Tahfidz Al Qur'an. (Studi Pesantren Darul Arqam Mubammadiyah Gombara Sulawesi Selatan). Jurnal Tarbawi pendidikan Agama Islam Volume 3 No.1, Januari - Juni 2018 ISSN : 2527-4082

Haidir dan salim. (2014). Strategi Pembelajaran suatu pendekatan 
bagaimana meningkatkan kegiatan belajar siswa secara transformatif. perdana publishing: kelompok penerbit perdana mulya sarana.

Jaya, Hendri. (2018). Tesis, pengaruh motivasi dan hafalan Alqur'an terhadap prestasi belajar pendidikan Agama islam. UIN Raden Intan Lampung.

Muhammad, Ahsin Skho. (2017). Menghafal Al-Qur'an, manfaat, keutamaan, keberkahan dan metode praktisnya. Jakarta: PT Qaf Media Kreatif.

Hidayah, Nurul. Strategi Pembelajaran Tahfidz Al-Qur'an Di Lembaga Pendidikan Ta'allum, Vol. 04, No. 01, Juni 2016

Ra'uf. Abdul Aziz Abdul. (2009). Anda Pun Bisa Menjadi Hafidz AlQur'an. Jakarta Timur: Markaz AlQur'an

Sa'dullah. (2008). 9 Cara Cepat Mengahafal Al-Qur'an. Depok: gema insani.

Supian DKK.(2018) Pendidkan Agama Islam berbasis akarakter dan moderasi Islam. Cetakan ix. Ciputat: GP Press Group.

Wahid, Alawiyah. (2015). Cara Cepat Bisa Menghafal Al-Qur'an. Yogyakarta: Diva Press.

Made, Wena. (2013). Strategi Pembelajaran inovatif kontemporer. Jakarta: Bumi Aksara.

Yahya bin „Abdurrazaq al-Ghausani. (2014) Metode Cepat Hafal AlQur'an. Solo: Perpustakaan Nasional 